\title{
PENGARUH IKLIM ORGANIASI DAN ETOS KERJA TERHADAP KINERJA KARYAWAN PT. CHAROEN POKPHAND INDONESIA MEDAN DENGAN MOTIVASI SEBAGAI VARIABEL INTERVINING
}

\author{
Sinar Ritonga \\ Universitas Katolik Santo Thomas Medan Jl. Setia Budi No. 479F, 20132, Indonesia \\ e-mail: sinarritonga58@gmail.com
}

\begin{abstract}
The purpose of this study is to determine the influence of organizational climate and work ethic on employee performance at PT. Charoen Pokphand Indonesia Medan with motivation as an intervining variable. The population in this study were all company employees as many as 62 people. Taking into account the relatively small number of members of the population, all members of the population are the object of research. The types and sources of data used in this study are primary data are data obtained through interviews, and through the distribution of questionnaires to responde, secondary data is data obtained through document collection using the documentation method. The analysis technique used is multiple linear regression analysis. The results showed that work climate and work ethic partially and simulutanly had a significant effect on work motivation and work climate, work ethic and work motivation partially and significantly had a positive and significant effect on employee performance.
\end{abstract}

Keywords: Employee performance, work climate, work ethic, and work motivation

\section{PENDAHULUAN}

Kinerja merupakan masalah yang kompleks, karena mencakup masalah teknis, masalah manajerial, individu karyawan, pemimpin dan faktor eksternal lainnya. Kinerja adalah suatu pendekatan interdisipliner untuk menentukan tujuan yang efektif, pembuatan rencana, aplikasi penggunaan cara yang produktif untuk menggunakan sumber-sumber secara efisien. Kinerja mengikutsertakan pendayagunaan secara terpadu, sumberdaya manusia, ketrampilan, barang modal, teknologi, manajemen, informasi dan sumber lain.

Masalah kinerja tentu tidak terlepas dari proses, hasil dan daya guna, disebabkan kinerja merupakan hasil kerja secara kualitas dan kuantitas yang dicapai oleh seorang karyawan dalam melaksanakan tugasnya sesuai dengan tanggung jawab yang diberikan kepadanya. Apabila kinerja didefinisikan sebagai pencapaian hasil atau tingkat pencapaian tingkat organisasi, dan kinerja disebut sebagai performance yang memiliki arti suatu hasil kerja yang dapat dicapai oleh seseorang atau sekelompok orang dalam suatu organisasi sesuai dengan wewenang dan tanggung jawab masing-masing dalam rangka mencapai tujuan organisasi secara legal, tidak melanggar hukum dan sesuai dengan moral maupun etika.

Untuk mewujudkan kinerja unsur Sumber Daya Manusia (SDM) memiliki posisi yang sangat penting dan menentukan di dalam organisasi. Keberhasilan organisasi sangat ditentukan oleh kualitas orang-orang yang bekerja di dalamnya.Perubahan lingkungan yang begitu cepat, menuntut kemampuan SDM dalam menangkap fenomena perubahan, menganalisa dampak terhadap organisasi, dan menyiapkan langkah-langkah guna menghadapi kondisi tersebut. Menyimak kenyataan ini, maka peran manajemen SDM dalam organisasi tidak hanya sekedar administratif tetapi justru lebih mengarah pada bagaimana mampu mengembangkan potensi SDM agar menjadi kreatif dan inovatif.

Ada beberbagai cara untuk meningkatkan kinerja karyawan seperti menciptakan iklim organisasi, etos kerja dan memotivasi karyawan itu sendiri.Iklim organisasijuga merupakan iklim organisasi yang diartikan sebagai lingkungan manusia tempat para pekerja melakukan pekerjaannya, merupakan hal yang tidak dapat dilihat dan disentuh, tetapi ada dan dapat dirasakan selama seseorang bekerja dalam organisasi. Demikian jugaiklim organisasi diartikan sebagai persepsi tentangkebijakan, praktek-praktek dan prosedur-prosedur 
organisasional yang dirasa dan diterima oleh individu-individu dalam organisasi, ataupunpersepsi individu terhadap tempatnya bekerja. Demikian juga peranan etos kerja sangat menentukan untuk meningkatkan kinerja karyawan. Seorang karyawan harus memiliki sikap kerja yang baik, menjadikan pekerjaan sebagai tanggung jawab untuk meningkatkan kinerja karyawan.Perilaku karyawan yang ideal adalah yang menunjukkan kearifannya yang ditandai oleh kemampuannya melihat yang tidak terlihat, mendengar yang tidak terdengar. Hal ini antara lain ditunjukkan oleh kemampuannya untuk memaknakan angka-angka yang biasa digunakan didalam kegiatan produksi dan transaksi sedemikian sehingga moral dan idealisme yang melandasi angka-angka itu dapat dimunculkan.

Agar kinerja karyawan semakin maksimal maka karyawan harus dimotivasi, harus dikelola dengan cepat, mana kala tidak dikendalikan akan berpengaruh terhadap jalannya kegiatan lembaga dalam pencapaian tujuan dan akan bergantung pula kepada keefektifan dan keefisienan dalam pelaksanaan tugas dan kewajibannya.

Untuk memperoleh kinerja karyawan yang optimal tidak cukup dengan meyakinkan bahwa karyawan telah memiliki pengetahuan dan ketrampilan yang diisyaratkan bagi sesuatu pekerjaan. Melainkan, harus mampu menciptakan dan membangun paradigma untuk mencapai tujuan perusahaan. Kondisi ini hanya bisa dicapai dan dilaksanakan apabila karyawan memahami benar sikap dalam bekerja dan motivasi kerja. Salah satu upaya memahami motivasi kerja karyawan adalah untuk menganalisis kebutuhannya sesuai dengan intensitasnya. Artinya, kebutuhan setiap karyawan itu berbeda satu sama lain bahkan bagi orang lain tidak bermanfaat.

Meskipun iklim organisasi, etos kerja dan motivasi telah diberikan kepada karyawan khususnya kepada karyawanpegawai Charoen Pokphand Indonesia Medan, namun tidak serta merta diimbangi dengan kinerja yang maksimal. Kenyataannya berdasarkan hasil pengamatan sementara di lapangan ternyata iklim organisasi, etos kerja dan motivasi di perusahaan tersebut belum dijalankan dengan optimal.

Jika diamati dilapangan iklim organisasi yang di perusahaan Charoen Pokphand Indonesia Medan, belum memiliki iklim organisasi yang seimbang dimana terdapat peraturan dan prosedur yang belum terstruktur dan tersusun dengan baik sehingga karyawan kurang leluasa dalam melakukan penyesuaian diri terhadap tugas - tugas yang diberikan, lingkungan kerja yang terasa kaku sehingga akan berdampak terhadap perilaku dari karyawan. Turunnya semangat kerja karyawan, tidak disiplin dan tidak loyal terhadap pekerjaan dan perasaan terpaksa dalam bekerja.

Pada hal semangat bekerja karyawan sangat dibutuhkan untuk mencapai produktivitas yang diharapkan perusahaan.Pada hal karyawan perlu diberikan kebebasan dalam bekerja, agar menjadi karyawan yang kreatif, berwawasan dan berdedikasi, namun kebutuhan karyawan untuk berkembang seperti kebutuhan akan harga diri maupun aktualisasi diri seperti yang diciptakan oleh para ahli motivasi kurang diperhatikan.

Karena itu, iklim organisasi, etos kerja dan motivasi menjadi berdampak terhadap pencapaian kinerja karyawan diperusahaan Charoen Pokphand Indonesia Medan. Salah satu dampak yaitu target produksi yang ditetapkan selama dua tahun belum dapat dicapai. Seperti Tahun 2015 target 105.000 ton tercapai 94.000 ton,dan tahun 2016 target 180.000 ton raliasasi hanya sebesar 103.000 ton

Berdasarkan latar belakang tersebut, peneliti merasa tertarik untuk mengadakan penelitian lebih lanjut mengenai : Pengaruh iklim organisasi danetos kerja terhadap kinerja karyawan PT Charoen Pokphand Indonesia Medandengan motivasi sebagai variabel intervening.

\section{TINJAUAN PUSTAKA}

\section{A. Iklim Organisasi}


Menurut Gibson, dkk (1997) bahwa iklim organisasi sebagai karakteristik yang membedakan suatu organisasi dengan organisasi lainnya, dan karakteristik ini dapat mempengaruhi perilaku orang-orang dalam organisasi. Sedangkan Landy dan Trumbo (1980) mengemukakan bahwa iklim organisasi adalah pemikiran yang menggambarkan persepsi anggota terhadap karakteristik obyektif organisasi.Definisi yang senada mengatakan bahwa iklim organisasi merupakan kualitas lingkungan internal suatu organisasi yang dialami oleh anggota-anggotanya, mempengaruhi perilaku serta dapat tergambar dari seperangkat karakteristik atau atribut khusus dari organisasi tersebut (Taguiri\& Litwin dalam Steers, 1985).Karakteristik dari iklim organisasi ini secara nyata menggambarkan suatu organisasi memperlakukan anggota-anggotanya.Berdasarkan penjelasan di atas maka diambil kesimpulan bahwa iklim organisasi adalah kualitas lingkungan internal yang dialami oleh anggota-anggotanya, mempengaruhi sikap dan perilaku serta dapat tergambar dalam sejumlah nilai karakteristik khusus dari suatu organisasi dan disebut sebagai kepribadian organisasi tersebut yang merupakan pemikiran hasil persepsi dari anggota organisasi.

\section{B. Dimensi Iklim Organisasi}

Menurut Kelneer dalam Lila (2002) bahwa ada 6 (enam) dimensi iklim organisasi diantaranya adalah: (1) flexibilityconformity, (2) resposibility, (3) standards, (4) reward, (5) clarity, dan (6) temacommitment.Sementara itu Lussier dalam Barkah (2002) menyatakan bahwa dimensi iklim organisasi diantaranya adalah:

1. Struktur merupakan tingkat paksaan yang dirasakan karyawan karena adanya peraturan dan prosedur yang terstruktur dan tersusun.

2. Responbility merupakan tingkat pengawasan yang dilakukan organisasi dan dirasakan oleh para karyawan.

3. Reward merupakan tingkat penghargaan yang diberikan atas usaha karyawan.

4. Warnt berkaitan dengan tingkat kepuasan karyawan yang berkaitan dengan karyawan dalam organisasi.

5. Support berkaitan dengan dukungan kepada pegawa i di dalam melaksakan tugas-tugas organisasi. Dukungan seperti dapat berasal dari pimpinan ataupun rekan kerja.

6. Organizatiol indetity and loyalty berkaitan dengan perasaan bangga akan keberadaannya dalam organisasi dan kesetiaan yang ditunjukkan selama masa kerjanya.

7. Risk berkaitan dengan karyawan diberi ruang untuk melakukan atau mengambil resiko dalam menjalankan tugas sebagai sebuah tantangan.

Iklim organisasi yang terbuka memacu karyawan untuk mengutarakan kepentingan dan ketidakpuasan tanpa adanya rasa takut akan tindakan balasan dan perhatian. Ketidakpuasan seperti itu dapat ditangani dengan cara yang positif dan bijaksana. Iklim keterbukaan bagaimanapun juga hanya tercipta jika semua anggota memiliki tingkat keyakinan yang tinggi dan mempercayai keadilan tindakan iklim organisasi penting untuk diciptakan karena merupakan persepsi seorang tentang apa yang diberikan oleh organisasi dan dijadikan dasar bagi penentuan tingkah laku anggota selanjutnya. Menurut Sedarmayanti, (2007)bahwa faktor-faktor yang mempengaruhi iklim kerja yaitu: (1) struktur organisasi, (2) kebijakan dan praktik manajerial, (3) teknologi, dan (4) lingkungan eksternal

\section{Etos Kerja}

Etos kerja dapat diartikan konsep tentang kerja atau paradigma kerja yang diyakini oleh seseorang atau sekelompok orang sebagai baik dan benar yang diwujudnyatakan melalui perilaku kerja mereka secara khas (Sinamo, 2003).Etos kerja sebagai semua kebiasaan baik yang berlandaskan etika yang harus dilakukan di tempat kerja, seperti: disiplin, jujur, tanggung jawab, tekun,sabar, berwawasan, kreatif, bersemangat, mampu bekerja sama, sadarlingkungan, loyal, berdedikasi, bersikap santun, seorang pekerja atau pemimpin betapa hebat kepandaian/kecakapannya, tetapi tidak jujur atau tidak bertanggung jawab, tidak 
disiplin atau tidak loyal, misalnya apalagi tak mampu bekerja sama, pasti merugikan perusahaan. Hal tersebut tidak dikehendaki terjadi.

\section{Etos Kerja Profesional}

Menurut Sinamo (2013) bahwa etos kerja profesional adalah seperangkat perilaku kerja positif dan bermutu tinggi yang berakar pada kesadaran yang jernih dan keyakinan yang kuat pada paradigma kerja yang holistik. Istilah paradigma sendiri berarti konsep utama tentang kerja itu sendiri yang mencakup idealisme yang mendasarinya, prinsip-prinsip yang mengaturnya, nilai-nilai luhur yang menggerakkannya, sikap-sikap mulia yang dilahirkannya dan standar-standar tinggi yang hendak dicapainya; termasuk karakter utama, pikiran pokok, kode etik, kode moral dan kode perilaku para pemeluknya.

Sinamo (2013) mengemukakan bahwa manusia itu pada dasarnya adalah pencari kesuksesan. Arti sukses dipandang relatif oleh sebagian masyarakat dari segi pencapaiannya, namun ada satu hal yang tetap dilihat sama oleh masyarakat dari zaman apapun yaitu cara untuk mencapai kesuksesan dengan delapan etos kerja berikut ini: (1) Kerja Adalah Rahmat, (2) Kerja Adalah Amanah, (3) Kerja Adalah Panggilan, (4) Kerja adalah Aktualisasi, (5) Kerja adalah Ibadah, (6) Kerja adalah Seni, (7) Kerja adalah Kehormatan, (8) Kerja adalah pelayanan

\section{E. Definisi dan Azas-Azas Motivasi}

Menurut Hasibuan (2002) motivasi berasal dari kata dasar motif yang mempunyai arti suatu perangsang, keinginan dan daya pengerak kemauan bekerja seseorang.Motivasi adalah data penggerak yang menciptakan kegairahan kerja seseorang agar mereka mau bekerjasama dengan efektif dan terintegrasi dengan segala daya upayanya untuk mencapai kepuasan.Konsep motivasi memegang peranan penting bagi seseorang dalam mengerakkan, mengarahkan segala daya upaya dan potensi diri ke arah pemanfaatan yang paling optimal sesuai dengan batas kemampuan seorang manusia, yang tentunya dapat ditunjang dengan bantuan sarana, prasarana berupa alat, uang, material, metode dan lain sebagainya. Sebaliknya dilihat dari konsep statis maka motivasi akan nampak sebagai kebutuhan sekaligus sebagai perangsang untuk dapat mengerakkan dan mengarahkan potensi daya kerja manusia tersebut ke arah yang diinginkan.

Maslow dalam Winardi (2011) mengemukakan sejumlah proposisi penting sebagai berikut:

1. Manusia merupakan makhluk yang serba berkeinginan (man is a wanting being). Ia senantiasa menginginkan sesuatu dan ia senantiasa menginginkan lebih banyak. Tetapi apa yang diinginkannya tergantung pada apa yang sudah dimiliki olehnya. Segera setelah salah satu di antara kebutuhan manusia dipenuhi muncullah kebutuhan lain. Proses tersebut tiada akhirnya. Ia berkelanjutan sejak manusia lahir hingga ia meninggal dunia. Maka sekalipun kebutuhan tertentu telah terpenuhi, kebutuhan-kebutuhan pada umumnya tidak mungkin terpuaskan seluruhnya.

2. Sebuah kebutuhan yang dipenuhi, bukanlah sebuah motivator perilaku. Hanya kebutuhan-kebutuhan yang tidak terpenuhi memotivasi perilaku. Untuk menjelaskannya perhatikan kebutuhan kita akan hawa udara. Kebutuhan tersebut hanya mempengaruhi perilaku kita, apabila kita tidak mendapatkannya atau mengalami ancaman tidak mendapatkan hawa udara yang kita perlukan. Dengan demikian hanya kebutuhankebutuhan yang belum terpenuhi menyebabkan timbulnya kekuatan-kekuatan besar atas apa yang dilakukan oleh seorang individu. Disini kita menemukan sebuah kebenaran penting yang sama sekali tidak diperhatikan oleh para supervisor yang senantiasa berupaya agar para karyawan senang selalu. Tujuan demikian tidak mungkin dicapai (impossible) dan ia mencampuradukan moril dengan motivasi.

3. Kebutuhan manusia diatur dalam suatu seri tingkatan-suatu hierarkhi menurut pentingnya masing-masing kebutuhan. Segera setelah kebutuhan-kebutuhan pada 
tingkatan lebih rendah kurang lebih terpenuhi, maka muncullah kebutuhan-kebutuhan pada tingkat berikut yang lebih tinggi dan menuntut pemuasan.

Jadi Maslow memandang seorang individu sehubungan dengan urutan kebutuhan yang dipredeteminasi, yang masing-masing memiliki peringkatnya sendiri bukan dalam bentuk rangsangan-rangsangan sederhana yang tidak terorganisasi.Maslow memandang motivasi seorang individu sebagai suatu urutan kebutuhan yang dipredeterminasi. Kebutuhan-kebutuhan fisiologikal, merupakan kebutuhan yang paling imperatif, tetapi secara psikologikal kebutuhan akan realisasi diri sangat penting bagi masing-masing individu.

Dari beberapa pendapat tersebut di atas, dapat disimpulkan bahwa motivasi merupakan suatu urutan kebutuhan yang dipredeterminasi yang merupakan proses internal dan eksternal yang menimbulkan dorongan pada diri seseorang dalam melaksanakan suatu kegiatan. Suatu organisasi diharapkan menciptakan karyawan yang selain memiliki ketrampilan teknis belaka juga mau bekerja secara semangat, giat dan antusias untuk mencapai hasil yang maksimal.

Dalam mendorong para bawahan agar memiliki motivasi yang kuat dalam bekerja perlu dilandasi oleh suatu azas-azas/prinsip-prinsip tertentu. Asas-asas motivasi menurut Hasibuan (2009) mencakup:

1. Asas Mengikut sertakan

2. Asas Komunikasi

3. Asas Pengakuan

4. Asas Wewenang yang Didelegasikan

5. Asas Adil dan Layak

6. Asas Perhatian Timbal Balik

\section{F. Teori-Teori Motivasi}

Menurut Nawawi (2003) bahwa ada 6 teori motivasi dari sudut psikologis yang dapat diimplementasikan di lingkungan suatu organisasi atau perusahaan, yaitu:

1. Teori hierarchi motivasi (Abraham Maslow). Setiap manusia memiliki kebutuhan masingmasing. Kebutuhan itu adalah kebutuhan fisik, psikologis dan spiritual. 5 kebutuhan dasar menurut Maslow disusun berdasarkan kebutuhan yang paling penting hingga yang tidak terlalu krusial sebagai berikut:

a. Kebutuhan fisiologis, misalnya sandang/pakaian, pangan/makanan, papan/rumah dan kebutuhan biologis seperti bernafas, buang air besar dan sebagainya.

b. kebutuhan keamanan dan keselamatan, misalnya bebas dari penjajahan, bebas dari ancaman, bebas dari rasa sakit, bebas dari teror dan lain sebagainya.

c. Kebutuhan sosial, misalnya memiliki teman, memiliki keluarga, kebutuhan cinta dari lawan jenis dan lain-lain.

d. Kebutuhan penghargaan, misalnya pujian, piagam, tanda jasa, hadiah dan banyak lagi lainnya.

e. Kebutuhan aktualisasi diri adalah kebutuhan dan keinginan untuk bertindak sesuka hati sesuai dengan bakat dan minatnya.

2. Teori dua faktor dari Hezberg. Teori ini mengemukakan ada dua faktor yang dapat memberikan kepuasan dalam bekerja yaitu:

a. Faktor sesuatu yang dapat memotivasi (motivatoir). Faktor ini antara lain adalah faktor prestasi (achievement), faktor pengakuan/penghargaan, faktor tanggungjawab, faktor memperoleh kemajuan dan perkembangan dalam bekerja khususnya promosi dan faktor pekerjaan itu sendiri.Herzberg (dalam Hogetts,2009) berpendapat bahwa apabila para manajer motivasi bawahannya ada dua faktor yang perlu diperhatikan pertama adalah faktor yang menimbulkan karyawan merasa sehat dan faktor motivator. 


\section{Volume 19 Nomor 1}

b. Kebutuhan kesehatan lingkungan (higiene factors). Jika faktor hygiene ada maka akan dapat membantu organisasi mengurangi ketidak puasan karyawan sebab mereka dalam kondisi sehat, sehat dari sudut keuangan, sehat dari sudut keamanan dan sebagainya. Sebaliknya, bila ini tidak ada, orang-orang tidak akan puas atau seperti orang merasa sakit tidak ada hygiene yang layak. Tetapi setelah faktor-faktor ini diciptakan manajer, bukan berarti orang lantas puas dan bebas dari segala penyakit. Sedangkan faktor motivator adalah merupakan kepuasan kerja yang apabila terdapat dalam pekerjaan akan menggerakkan tingkat motivasi yang kuat dan dapat menghasilkan prestasi yang lebih baik. Perbedaan utama antara heigenis dan motivator menurut Herzberg (dalam Koeswara. (2009) ialah bahwa hiegine tidak langsung berhubungan dengan pekerjaan, oleh karena itu ia menanamkannya faktor lingkungan kerja. Sedangkan motivator langsung berhubungan dengan pekerjaan untuk dapat memotivasi. Adapun prinsip yang harus diperhatikan seorang manajer untuk memotivasi karyawan diantaranya adalah:

1. Hilangkan beberapa pengendalian, tetapi pertahankan tanggunggugat.Tingkatkan ketanggunggugatan orang-orang atas pekerjaan

2. Berikan kepada seseorang suatu unit pekerjaan yang wajar dan sebagainya

3. Berikan wewenang tambahan kepada seorang karyawan dalam kegiatan yang merupakan kebebasan pekerjaan.

4. Sediakan laporan berkala langsung untuk pekerja sendiri dan tidak hanya untuk penyelia saja.

5. Perkenalkan tugas-tugas yang lebih baru dan lebih sulit yang sebelumnya belum pernah ditangani.

6. Berikan kepada orang-orang langkah-langkah atau tugas-tugas tertentu sehingga mereka dapat menjadi ahli

Ketujuh prinsip tersebut perlu diterapkan oleh setiap manajer agar karyawan merasa puas dalam melaksanakan pekerjaannya, yang pada akhirnya faktor-faktor motivators tersebut dapat lebih mudah dicapai dan akibatnya karyawan merasa senang bekerja.

3. Teori prestasi (achievement) dari Mc. Clelland. Teori ini mengklasifikasikan motivasi berdasarkan akibat suatu kegiatan yang dicapai termasuk juga dalam bekerja dengan kata lain kebutuhan berprestasi merupakan motivasi dalam melaksanakan pekerjaan. Kebutuhan ini memerlukan dan mengharuskan seorang pekerja/ karyawan melakukan kegiatan belajar agar menguasasi ketrampilan/keahlian yang memungkinkan seorang pekerja/ karyawan mencapai suatu prestasi berikutnya. Implementasinya di lingkungan sebuah organisasi antara lain:

a. Para pekerja terutama manajer/pimpinan dan tenaga kerja merupakan kunci pokok, menyukai dan memikul tanggungjawab dalam bekerja karena kemampuan melaksanakannya merupakan prestasi bagi yang bersangkutan.

b. Dalam bekerja yang memiliki resiko kerja, para pekerja menyukai pekerjaan yang beresiko rendah (moderat). Pekerjaan yang beresiko tinggi dapat mengecewakannya karena jika gagal berarti tidak atau kurang berprestasi. Sebaliknya juga kurang menyukai pekerjaan yang beresiko rendah atau tanpa resiko yang dapat mengakibatkan pekerjaan tersebut diklasifikasikan tidak/kurang berprestasi, baik berhasil maupun gagal melaksanakannya.

c. Pekerja yang berprestasi tinggi menyukai informasi sebgai umpan balik karena selalu terdorong unutk memperbaiki dan meningkatkan kegiatannya dalam bekerja. Dengan demikian peluangnya untuk meningkatkan prestasi kerja akan lebih besar.

d. Kelemahan yang dapat merugikan pekerja yang berprestasi tinggi lebih menyukai bekerja mandiri sehingga kurang positif sebagai manajer. Kemandirian itu dimaksudkan untuk menunjukan prestasinya yang mungkin lebih daripada orang lain. 
4. Teori penguatan (reinforcement). Teori ini banyak dipergunakan dan fundamental sifatnya dalam proses bekerja dengan mempergunakan prinsip yang disebut hukum ganjaran atau low of effect. Hukum itu mengatakan bahwa suatu tingkah laku yang mendapatkan ganjaran menyenangkan akan mengalami penguatan dan cenderung untuk diulangi misalnya setiap memperoleh nilai baik dalam bekerja mendapatkan pujian atau hadiah maka cenderung unutk mempertahankan dengan mengulangi proses yang pernah dilakukan. Sebaliknya suatu perbuatan yang tidak mendapatkan ganjaran tidak mengalami penguatan dan cenderung tidak mengulangi atau bahkan dihindari.

Secara operasional implementasi teori ini di lingkungan organisasi/perusahaan mengharuskan para pimpinan agar mereka melaksanakan tugas dan tanggungjawabnya dapat memberikan wujud penguatan bagi kegiatan pelaksanaan pekerjaan secara efektif dan efesien.Hal ini dapat diwujudkan dalam bentuk insentif sebagai sebuah perangsang agar menghasilkan respon positif seperti kreativitas, produktivitas dan prestasi kerja yang lainnya.

5. Teori Harapan. Pada prinsipnya teori ini terdapat hubungan yang erat antara pengertian seseorang mengenai suatu tingkah laku dengan hasil kerja yang ingin diperolehnya sebagai harapan.Seseorang melakukan pekerjaan dipengaruhi oleh jenis dan kualitas kemampuan yang dimilikinya yang diwujudkan berupa ketrampilan, keahlian dan kemahiran dalam bekerja. Apabila ada kesesuaian antara pekerja dengan yang dikerjakannya baik dälam hal ketrampilan, kemahiran dan keahlian yang dimilikinya maka akan memperoleh hasil kerja sesuai dengan yang diharapkan dan harapan itu menjadi suatu ganjaran yang akan memberikan suatu kepastian tersendiri bagi pekerja.

6. Teori tujuan motivasi. Teori tujuan motivasi implementasinya dalam lingkungan perusahaan atau lingkungan organisasi dapat dilakukan sebagai berikut:

a. Tujuan organisasi/perusahaan merupakan fokus utama dalam bekerja oleh karena itu para pimpinan perlu untuk merumuskannya secara jelas dan terperinci agar mudah dipahami oleh para pekerja untuk itu para pimpinan perlu membantu pekerja jika mengalami kesulitan dalam memahami dan menyesuaikan diri dengan tujuan yang hendak dicapai.

b. Tujuan organisasi/perusahaan merupakan tingkat intensitas pelaksanaan pekerjaan sesuai dengan tingkat kesulitan pencapaiannya. Untuk itu para pimpinan perlu merumuskan tujuan yang bersifat menantang sesuai dengan kemampuan pekerja yang ikut mewujudkannya.

c. Tujuan yang sulit menimbulkan kegigihan dan ketekunan dalam bekerja, para pimpinan perlu menghargai para pekerja yang berhasil mewujudkan tujuan organisasi.

\section{G. Jenis-Jenis Motivasi}

Jenis-jenis motivasi merupakan unsur yang sangat penting untuk memotivasi karyawan dalam organisasi adalah:

1. Motivasi Positif (insentif positif), pimpinan memotivasi bawahan atau karyawan dengan memberikan hadiah kepada mereka yang berprestasi baik. Dengan motivasi positif ini semangat kerja karyawan akan meningkat, karena manusia pada umumnya senang menerima yang baik-baik saja.

2. Motivasi Negatif (prestasi rendah), pimpinan memotivasi bawahan atau karyawan dengan memberikan hukuman kepada mereka yang pekerjaannya kurang baik (prestasi rendah). Dengan memotivasi negatif ini semangat kerja karyawan dalam jangka waktu pendek akan meningkat, karena mereka takut di hukum, tetapi untuk jangka waktu panjang dapat berakibat kurang baik.(Hasibuan, 2001)

Selanjutnya Handoko berpendapat (2001) bahwa jika dilihat atas dasar fungsinya motivasi terbagi atas: 
1. Motivasi intrinsic. Berbagai kebutuhan keinginan dan harapan terdapat di dalam pribadi seseorang menyusun motivasi internal orang tersebut.Kekuatan ini mempengaruhi pribadinya dengan menentukan berbagai pandangan yang menurut giliran untuk memimpin tingkah laku dalam situasi yang khusus.

2. Motivasi Ekstrinsik. Motivasi ekstrinsik adalah perilaku yang terbentuk akibat adanya keinginan yang terbentuk akibat adanya keinginan mendapatkan ganjaran materi atau sosial atau untuk menghindari suatu hukuman.

\section{H. Kinerja Karyawan}

Menurut Triton, (2010) kinerja adalah tentang melakukan pekerjaan dan hasil yang dicapai dari. Pekerjaan diartikan bahwa implementasi yang dilakukan hendaknya berorientasi pada kemampuan, kompetensi, motivasi dan kepentingan.Kinerja adalah suatu kemampuan dan kecakapan seorang karyawan dan lain sebagainya yang dihasilkan oleh seorang karyawan yang bersangkutan. Jadi dapat disimpulkan bahwa kinerja adalah suatu keadaan pelaksanaan kerja disuatu organisasi yang didasarkan pada perasaan emosional seseorang karyawan. Hal ini akan tampak dari sikap karyawan terhadap aspek-aspek yang dihadapinya di lingkungan kerja yang menyangkut penyesuaian diri yang sehat termasuk didalamnya gaji, kondisi fisik, dan psikologis maupun aturan hukum yang ada.

\section{Faktor-faktor yang Mempengaruhi Kinerja}

Menurut Robbins (2006) bahwa faktor-faktor yang mempengaruhi kinerja adalah sebagai berikut : (a) iklim organisasi, (b) kepemimpinan, (c) kualitas pekerjaan, (d) kemampuan kerja, (e) inisiatif, (f) motivasi, (g) daya tahan/ kehandalan, (h) kuantitas pekerjaan, dan (i) disiplin kerja

\section{J. Indikator Penilaian Kinerja}

Menurut Riduwan (2002) bahwa indikator yang digunakan untuk menilai kinerja karyawan antara lain adalah sebagai berikut :

1. Inisiatif mencari langkah yang terbaik

2. Menguasai Job Description.

3. Hasil yang dicapai

4. Tingkat kemampuan kerjasama

5. Ketelitian

6. Tingkat kesesuaian tugas dengan perintah

7. Tingkat kualitas hasil kerja

8. Tingkat ketepatan penyelesaian kerja

9. Tingkat kuantitas hasil kerja

Berhasil atau tidaknya organisasi dalam pencapaian hasil sangat dipengaruhi oleh tingkat kinerja dari karyawan secara individual maupun secara kelompok, dengan asumsi bahwa semakin baik kinerja karyawan maka diharapkan kinerja organisasi akan semakin baik pula.

\section{K. Mengukur Kinerja Karyawan}

Pengukuran terhadap kinerja suatu organisasi merupakan hal yang sangat penting, karena akan dijadikan sebagai standar keberhasilan suatu oganisasi dalam kurun waktu tertentu. Organisasi dapat dikatakan berhasil jika terdapat indikator-indikator atau ukuranukuran capaiaan yang mengarah pada visi dan misi organisasi. Tanpa adanya pengukuran kinerja, akan sulit dicari pembenaran yang lgosi atas pencapaiaan misi organisasi. Hasil pengukuran kinerja mempunyai makna ganda yaitu pengukuran sendiri (feedback) dan evaluasi kinerja organisasi dimana kedua hal tersebut harus terlebih dahulu ditentukan tujuan dari program secara jelas.Ada beberapa indikator yang dapat digunakan untuk penilaiaan 
kinerja diantaranya: (1) Kualitas (Quality), (2) Kuantitas (Quantity), (3) Ketepatan Waktu (Timeliness), (4) Keefektifan Biaya (Cost Effectiveness), dan (5) Perlu Pengawasan (Need for Supervision)

\section{METODE PENELITIAN}

\section{A. Desain Penelitian}

Penelitian ini secara empiris bertujuan memperoleh bukti pengaruh iklim organiasi dan etos kerja terhadap kinerja karyawan PT. Charoen Pokphand Indonesia Medan dengan motivasi sebagai variabel intervining. Oleh karena itu, penelitian ini adalah bersifat deskriptif dan ekplanatori.

\section{B. Populasi dan sampel}

Populasi penelitian ini adalah karyawan PT. Charoen Pokphand Indonesia Medan sebanyak 62 orang. Memperhatikan jumlah anggota populasi yang relatif sedikit maka seluruh anggota populasi menjadi obyek penelitian. Dengan demikian penelitian ini dilakukan dengan metode sensus.

\section{Jenis dan Sumber Data}

Jenis dan sumber data yang digunakan dalam penelitian ini adalah :

a. Data primer adalah data yang diperoleh melalui wawancara (intervew), dan melalui penyebaran daftar pertanyaan (questionaire) kepada responden, yaitu karyawan pada PT. Charoen Pokphand Indonesia di Medan.

b. Data sekunder adalah data yang diperoleh melalui pengumpulan dokumen dokumen dari PT. Charoen Pokphand Indonesia di Medan.

\section{Teknik Pengumpulan Data}

Teknik pengumpulan data dalam penelitian ini dilakukan menggunakan kuesioner sebagai alat pengumpulan data. Pilihan jawaban responden yang dugunakan dalam kuesioner menggunakan skala ordinal dengan skala Likert.

\section{E. Variabel Penelitian Dan Definisi Operasional Variabel}

Dalam penelitian ini terdapat 3 (tiga) jenis variabel, yaitu :

1. Varibel bebasadalah

a. Iklim organisasi $\left(\mathrm{X}_{1}\right)$ yaitu kualitas lingkungan internal yang dialami oleh anggotaanggotanya, mempengaruhi sikap dan perilaku serta dapat tergambar dalam sejumlah nilai karakteristik khusus dari suatu organisasi dan disebut sebagai kepribadian organisasi tersebut yang merupakan pemikiran hasil persepsi dari anggota organisasi, dengan indikator: struktur, tugas dan tanggungjawab, kehangatan dan dukungan, imbalan dan sanksi, pertentangan, standar kinerja dan pengharapan dan identitas organisasi.

b. Etos kerja $\left(\mathrm{X}_{2}\right)$ adalah seperangkat perilaku kerja positif dan bermutu tinggi, yang berakar pada kesadaran yang jernih dan keyakinan yang kuat pada paradigma kerja yang holistic dengan indikator: bekerja tulus penuh rasa syukur, bekerja tuntas penuh integritas, bekerja benar penuh tanggungjawab, bekerja keras penuh semangat, bekerja serius penuh kecintaan, bekerja cerdas penuh kreativitas, bekerja tekun penuh keunggulan dan bekerja sempurna penuh kerendahan hati

2. Variabel intervening yaitumotivasi (Z), adalah kemauan dan kerelaan karyawan untuk mengerahkan kemampuan dan waktunya dalam menyelenggarakan berbagai kegiatan yang menjadi tanggungjawabnya dan menunaikan kewajibannya dalam rangka pencapaian tujuan dan berbagai sasaran dalam organisasi dengan indikator: upah, insentif, jaminan, hubungan kerja, kondisi kerja dan penghargaan. 
3. Variabel terikat adalah kinerja karyawan(Y)karyawan adalah dalah Konsep yang memandangpengabdian atau dedikasipegawai terhadap pekerjaansebagai nilai yang sangat berharga dengan indikator: kualitas pekerjaan, kuantitas pekerjaan, ketepatan waktu, efisiensi dan perlu pengawasan

\section{F. Metode Analisis}

Sebelum data diolah dan dianalisis, maka terlebih dahulu dilakukan pengujian validitas dan pengujian realiabilitas. Uji Validitas yang akan digunakan adalah tehnik korelasi product moment Pearson, dengan ketentuan bahwa suatu instrument penelitian dikatakan valid jika: koefisien korelasi product moment $>0.3$ dan sebaliknya.Uji reliabilitas dengan menggunakan metode Alpha Cronbach's, suatu instrument dikatakan reliabel apabila nilai alpha lebih besar dari 0,6 dengan rumus:

\section{G. Uji Multikolinieritas}

Uji multikolinieritas bertujuan untuk menguji apakah dalam model regresi ditemukan adanya korelasi antar varibel bebas. Multikolinieritas terjadi apabila :Nilaitolerance $(T O L)<0,1$ danVariance inflation factor (VIF) $>10$.

\section{H. Uji Heteroskedastisitas}

Deteksi heteroskedastisitas dalam penelitian ini dilakukan dengan metode analisis grafik Scatter Plot dengan memplotkan nilai ZPRED (nilai prediksi) dengan SRESID (nilai residualnya).Model yang baik didapatkan jika tidak terdapat pola tertentu pada grafik, seperti mengumpul di tengah, menyempit kemudian melebar atau sebaliknya melebar kemudian menyempit.

\section{Model Analisis}

Teknik analisis yang digunakan adalah persamaan regresi linear berganda dengan rumus sebagai berikut:

$$
\begin{aligned}
& \mathrm{Z}=\mathrm{a}+\mathrm{b} 1 \mathrm{X} 1+\mathrm{b} 2 \mathrm{X} 2 \\
& \mathrm{Y}=\mathrm{a}+\mathrm{b} 1 \mathrm{X} 1+\mathrm{b} 2 \mathrm{X} 2+\mathrm{b} 3 \mathrm{Z} \\
& \mathrm{Dimana}: \quad \mathrm{a}=\text { konstanta } \\
& \mathrm{bi}=\text { koefisien regresi } \\
& \mathrm{X} 1=\text { iklim kerja } \\
& \mathrm{X} 2=\text { etos kerja } \\
& \mathrm{Z}=\text { motivasi } \\
& \mathrm{Y}=\text { kinerja karyawan }
\end{aligned}
$$

Untuk menguji hipotesis digunakan uji F untuk mengetahui pengaruh secara simultan dan uji t,untuk mengetahui pengaruh secara parsial.

\section{HASIL DAN PEMBAHASAN}

\section{A. Analisis Deskriptif Data Responden}

Adapun karakteristik responden yang menjadi sampel dalam penelitian ini menurut jenis kelamin laki-laki sebanyak 53 orang atau 85,48 persen, responden dengan jenis kelamin perempuan sebanyak 9 orang atau 14,52 persen. Responden menurut usia adalah yang berusia 20 - 27 tahun sebanyak 12 orang atau 19,35 persen, responden yang berusia 28 - 35 tahun sebanyak 25 orang 40,32 persen, yang berusia 35 - 42 sebanyak 16 orang atau 25,81 persen, yang berusia 43 - 50 sebanyak 7 orang atau 11,29 persen dan yang berusia $>$ 51 sebanyak 2 orang atau 3,23 persen. Responden menurut tingkat pendidikan adalah tingkat pendidikan SMA/SMK sebanyak 17 orang atau 27,42 orang, pendidikan Diploma (D3) sebanyak 26 orangatau 41,94 orang, dan pendidikan Sarjana (S1) sebanyak 19 orang atau 30,65 persen. Responden menurut status perkawinan adalah responden dengan status 


\section{Volume 19 Nomor 1}

menikah sebanyak 51 oarang atau 82,26 persen dan responden dengan status tidak menikah sebanyak 11 orang atau 17,74 persen.

\section{B. Uji Validitas dan Realiabilitas}

Hasil uji validitas dan reliabilitas dari variabel Iklim Organisasi, Etos Kerja, Motivasi dan Kinerja Karyawan diperoleh nila $r$ masing-masing dimensi variable telah melebihi nilai 0,30 dan nilai Cronbach's Alpha telah melebihi 0.50 sehingga dapat disimpulkan bahwa kuesioner tersebut dinyatakan valid dan reliabel.

\section{Uji Multikolinieritas}

Hasil uji multikilinieritas terhadap varabel iklim organisasi dan etos kerja diperoleh nilai Tolerance $0.778<1$ dan dan VIF $1.285<10$ untuk variabel Iklim organisasi dan Etos Kerja hal ini menunjukkan tidak terjadi multikolinieritas diantara kedua variable.

\section{Uji Heteroskedastisitas}

Hasil uji heteroskedastisitas disajikan pada gambar 1 di bawah ini.

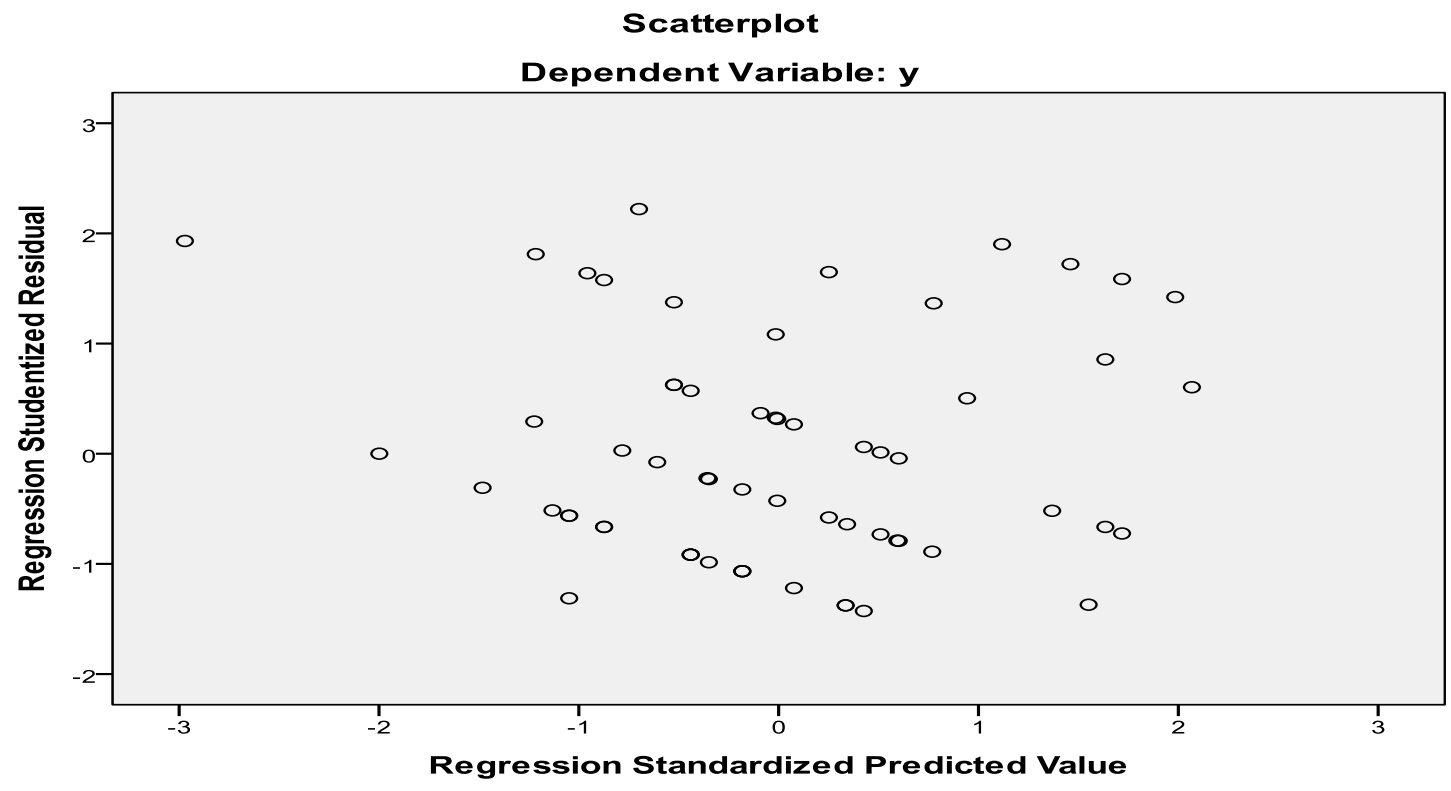

Gambar 1. Hasil uji heteroskedastisitas

Dari Gambar 1 di atas nampak bahwa titik menyebar secara acak dan tidak membentuk suatu pola tertentu yang jelas serta tersebar baik di atas maupun di bawah angka nol pada sumbu Y. Hal ini menunjukkan tidak terjadi gejala heteroskedasitisitas pada model regresi.

\section{E. Hasil Penelitian dan Pembahasan}

Hasil analisis pengaruh iklim organiasi dan etos kerja terhadap kinerja karyawan dengan motivasi sebagai variabel intervining disajikan pada Tabel 2 dan 3 berikut.

Tabel 2 Kinerja Coefficients ${ }^{a}$

\begin{tabular}{|c|c|c|c|c|c|c|}
\hline & & \multicolumn{2}{|c|}{$\begin{array}{l}\text { Unstandardized } \\
\text { Coefficients }\end{array}$} & \multirow{2}{*}{$\begin{array}{c}\begin{array}{c}\text { Standardized } \\
\text { Coefficients }\end{array} \\
\text { Beta }\end{array}$} & \multirow[b]{2}{*}{$\mathbf{t}$} & \multirow[b]{2}{*}{ Sig. } \\
\hline \multicolumn{2}{|c|}{ Model } & B & Std. Error & & & \\
\hline \multirow[t]{3}{*}{1} & (Constant) & 2.526 & 3.186 & & .793 & .431 \\
\hline & Iklim Kerja & .203 & .008 & .203 & 2.875 & .004 \\
\hline & Etos Kerja & 1.002 & .183 & .614 & 5.478 & .000 \\
\hline
\end{tabular}




\begin{tabular}{|c|c|c|c|c|c|c|}
\hline \multirow{2}{*}{\multicolumn{2}{|c|}{ Model }} & \multicolumn{2}{|c|}{$\begin{array}{l}\text { Unstandardized } \\
\text { Coefficients }\end{array}$} & \multirow{2}{*}{$\begin{array}{c}\begin{array}{c}\text { Standardized } \\
\text { Coefficients }\end{array} \\
\text { Beta }\end{array}$} & \multirow[b]{2}{*}{$\mathbf{t}$} & \multirow[b]{2}{*}{ Sig. } \\
\hline & & B & Std. Error & & & \\
\hline \multicolumn{7}{|c|}{ a. Dependent Variable: motivasi } \\
\hline \multirow[t]{4}{*}{1} & (Constant) & 6.002 & 2.049 & & 2.930 & .005 \\
\hline & Iklim Kerja & .121 & .042 & 132 & 2.881 & .007 \\
\hline & Etos Kerja & .167 & .061 & .284 & 2.752 & .008 \\
\hline & Motivasi & .337 & .062 & .549 & 5.436 & .000 \\
\hline
\end{tabular}

a. Dependent Variable: kinerja karyawan

Sumber : Hasil Pengolahan Data Penelitian 2018

Tabel 3. ANOVA

\begin{tabular}{|l|l|r|r|r|r|r|}
\hline \multicolumn{2}{|l|}{ Model } & Sum of Squares & \multicolumn{1}{c|}{ df } & Mean Square & \multicolumn{1}{c|}{ F } & Sig. \\
\hline \multirow{4}{*}{1} & Regression & 325.835 & 3 & 108.612 & 18.954 & .000 \\
\cline { 2 - 8 } & Residual & 332.359 & 58 & 5.730 & & \\
\cline { 2 - 8 } & Total & 658.194 & 61 & & & Sig. \\
\hline \multicolumn{2}{|l|}{ Model } & Sum of Squares & df & Mean Square & F & .009 \\
\hline \multirow{2}{*}{1} & Regression & 255.845 & 2 & 127.923 & 5.048 & \\
\cline { 2 - 8 } & Residual & 1495.074 & 59 & 25.340 & & \\
\hline
\end{tabular}

Sumber : Hasil Pengolahan Data Penelitian 2018

Dari Tabel 2 di atas menunjukkan bahwa variable iklim kerja dan etos kerja secara parsial berpengaruh positif dan signifikan terhadap motivasi kerja karyawan hal ini nampak dari masing-masing nilait hitung sebesar 2.875 dan 5.578 dengan tingkat signifikansi masingmasing sebesar 0.4 persen dan 0 persen, dan juga secara simultan variable iklim kerja dan etos kerja berpengaruh signifikan terhadap motivasi kerja karyawan hal ini nampak dari nilai $\mathrm{F}$ hitung sebesar 18.954 dengan tingkat signifikansi sebesar 0.0 persen. Dari Tabel 4 di atas menunjukkan bahwa variable iklim kerja, etos kerja dan motivasi secara parsial berpengaruh positif dan signifikan terhadap kinerja karyawan hal ini nampak dari masing-masing nilai $\mathrm{t}$ hitung sebesar 2.875, 5.578 dan 5.436 dengan tingkat signifikansi masing-masing sebesar 0.7 persen, 0.8 persen dan 0.0 persen, dan juga secara simultan variable iklim kerja, etos kerja dan motivasi berpengaruh signifikan terhadap kinerja karyawan hal ini nampak dari nilai $\mathrm{F}$ hitung sebesar 5.048 dengan tingkat signifikansi sebesar 0.9 persen.

Besarnya pengaruh langsung antara iklim kerja terhadap motivasi kerja adalah sebesar 0.203, pengaruh langsung antara etos kerja terhadap motivasi kerja adalah sebesar 0.284, pengaruh langsung antara iklim kerja terhadap kinerja karyawan adalah sebesar 0.132, pengaruh langsung antara iklim kerja terhadap kinerja karyawan adalah sebesar 0.284, pengaruh langsung antara motivasi kerja terhadap kinerja karyawan adalah sebesar 0.549 . Besarnya pengaruh tidak langsung antara iklim kerja terhadap kinerja karyawan melalui motivasi kerja adalah sebesar 0.11, pengaruh tidak langsung antara etos kerja terhadap kinerja karyawan melalui motivasi kerja adalah sebesar 0.34 . Besarnya pengaruh antara iklim kerja terhadap kinerja karyawan melalui motivasi kerja adalah sebesar 0.753 , pengaruh tidak langsung antara etos kerja terhadap kinerja karyawan melalui motivasi kerja adalah sebesar 1.163.

Berdasarkan analisis di atas nampak untuk meningkatkan kinerja karyawan pimpinan perusahaan hendaknya memperbaiki iklim organisasi melalui:struktur, tugas dan tanggungjawab, kehangatan dan dukungan, imbalan dan sanksi, pertentangan, standar kinerja dan pengharapan, identitas organisasi dan motivasi kerja melalui upah, insentif, jaminan, hubungan kerja, kondisi kerja, penghargaan atau melalui etos kerja melalui bekerja tulus penuh rasa syukur, bekerja tuntas penuh integritas, bekerja benar penuh 
tanggungjawab, bekerja keras penuh semangat, bekerja serius penuh kecintaan, bekerja cerdas penuh kreativitas, bekerja tekun penuh keunggulan, bekerja sempurna penuh kerendahan hati dan motivasi kerja melalui upah, insentif, jaminan, hubungan kerja, kondisi kerja, penghargaan.

\section{KESIMPULAN}

Berdasarkan hasil analisis dan pembahasan maka dapat ditarik kesimpulan dan saran sebegai beriktu:

a. Iklim kerja dan etos kerja secara parsial berpengaruh positif dan signifikan terhadap motivasi kerja dan Iklim kerja dan etos kerja secara simultan berpengaruh signifikan terhadap motivasi kerja.

b. Iklim kerja, etos kerja dan motivasi kerja secara parsial berpengaruh positif dan signifikan terhadap kinerja karyawan dan Iklim kerja, etos kerja dan motivasi kerja secara simultan berpengaruh signifikan terhadap kinerja karyawan.

c. Besarnya pengaruh langsung antara iklim kerja terhadap motivasi kerja adalah sebesar 0.203 antara etos kerja terhadap motivasi kerja adalah sebesar 0.284 , antara iklim kerja terhadap kinerja karyawan adalah sebesar 0.132 , antara iklim kerja terhadap kinerja karyawan adalah sebesar 0.284 , antara motivasi kerja terhadap kinerja karyawan adalah sebesar 0.549,

d. Besarnya pengaruh tidak langsung antara iklim kerja terhadap kinerja karyawan melalui motivasi kerja adalah sebesar 0.11 , antara etos kerja terhadap kinerja karyawan melalui motivasi kerja adalah sebesar 0.34 .

e. Besarnya pengaruh total antara iklim kerja terhadap kinerja karyawan melalui motivasi kerja adalah sebesar 0.753 , antara etos kerja terhadap kinerja karyawan melalui motivasi kerja adalah sebesar 1,163.

\section{DAFTAR PUSTAKA}

Davis, Keith dan Newstrom, John W. 2001.Perilaku Dalam Organisasi. Jakarta: PT.Erlangga.

Ghozali, Imam. 2009. Aplikasi Analisis Multivariate Dengan Program SPSS, Edisi Keempat. Universitas Diponegoro.

Gibson. 2003. Organisasi : Perilaku, struktur dan proses. Jakarta: Erlangga.

Hasibuan, H. Malayu S.P. 2003. Manajemen: Dasar, Pengertian, dan Masalah. Edisi Revisi. Jakarta: Bumi Aksara.

Lussier, N, Robert. 2005. Human Relations in Organization. Applications and Skill Building. New York : Mc Graw Hill.

Mangkunegara, Anwar Prabu. 2006. Evaluasi Kinerja SDM. Jakarta: Eresco.

Nazir, Moh., 2009. Metode Penelitian, Cetakan Keenam. Jakarta: Ghalia

Rivai dan Basri. 2004. Manfaat Penilaian Kinerja. Jurnal online http://jurnalsdm. blogspot.com/2009/04/penilaian-kinerja-karyawan-definisi.html (diaksestanggal 23 Agustus 2013)

Rivai, Veithzal. 2006. Manajemen Sumber Daya Manusia Untuk Perusahaan (Dari Teori Ke Praktek). Jakarta: PT. Raja Grafindo Persada.

Sapitra.2012. Pengaruh Iklim Organisasi terhadap Kepuasan Kerja Karyawan Hotel Kurnia Perdana Bandar lampung.Lampung : Universitas Lampung

Sastrohadiwiryo, Siswanto. 2003. Manajemen Tenaga Kerja Indonesia.Jakarta : Bumi Aksara.

Schuler, Randal S. dan Jackson, Susan E. 1996.Manajemen Sumber Daya Manusia Menghadapi Abad ke 21, Jilid 2, Edisi Keenam. Jakarta: Erlangga.

Simamora, Henry. 2004. Manajemen Sumber Daya Manusia. Edisi Ke-3.

Sinamo, Jansen H. 2003. Etos Kerja 21 Etos Kerja Profesional di Era Digital Global, Ed 1. Jakarta: Institut Darma Mahardika. 
Singarimbun, Masri, dan Effendi. 2006. Metode Penelitian Survei. Jakarta: LP3ES.

Steers, M Richard. 1985. Efektivitas Organisasi Perusahaan. Jakarta: Erlangga.

Sulistiyani, Ambar Teguh. 2003. Manajemen Sumber Daya Manusia. Edisi Pertama. Yogyakarta: Graha Ilmu.

Tasmara, Toto. 2002. Membangun Etos Kerja Islam. Jakarta: Gema Insani Pers.

Tika, Pabundu. 2006. Budaya Organisasi dan Peningkatan Kinerja Perusahaan. Jakarta: Bumi Aksara.

Wirawan. 2007. Budaya dan Iklim Organisasi: Teori, Aplikasi dan Penelitian. Jakarta: Salemba Empat. Yogyakarta: STIE YKPN.

Yusuf, Andri. 2013. Kinerja Dalam Rangka Penilaian Kerja. (online) http://sewank09.blogspot.com/2013/01/kinerja-dalam-rangka-penilaiankerja_ 6742.html (diakses tanggal 23 Agustus 2013)

Zulham, Muhammad. 2008. Analisis Pengaruh Budaya Organisasi dan Etos Kerja Terhadap Kinerja Pegawai Fakultas Ekonomi Universitas Sumatera Utara.Medan: Universitas Sumatera Utara.

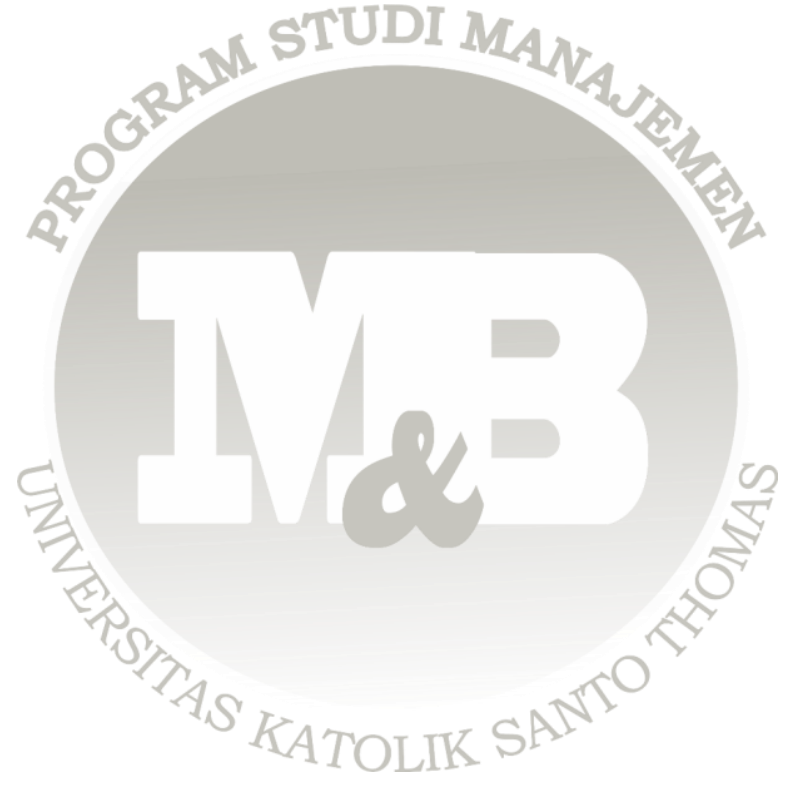

